\title{
Mothering and Gender Equality in Iceland: Irreconcilable Opposites?
}

\author{
Ingólfur V. Gíslason* and Sunna Símonardóttir** \\ *University of Iceland \\ E-mail: ivg@hi.is \\ ** University of Iceland \\ E-mail: sunnaks@hi.is
}

Iceland enjoys a reputation as one of the most gender equal countries in the world. It has also received much attention for an innovative approach to parental leave where fathers have three months of non-transferable leave, thereby encouraging active involvement of fathers in the caretaking of their children. This article focuses on the discrepancy between on the one hand the goals of the state of drawing men, particularly fathers, into traditional female dominated areas such as caregiving of infants and young children and on the other hand a discourse that equates motherhood with parenthood and promotes the ideology of intensive mothering.

Keywords: Gender equality, Iceland, motherhood, parenting.

\section{Introduction}

Iceland enjoys a reputation as one of the most gender equal countries in the world. The country has also received much attention for an innovative approach to parental leave where fathers have three months of non-transferable leave, thereby encouraging active involvement of fathers in the caretaking of their children. Around 90 per cent of fathers make use of their right to paternity leave and take on average around 100 days. Whilst the state has taken serious steps to involve fathers, there is a tendency to equate motherhood with parenthood while children are very young and promote an ideology of intensive mothering. A similar view now characterises the infant and maternity care service provided by the primary health care that seems to have partly fallen sway to mothercentred attachment focus. No longer are there special classes reserved solely for fathers in the antenatal courses, and no focused effort is made to increase the participation of fathers. On the contrary, as recent sociological research has shown; discourses on mothering in Iceland point to an intensification of mothering by constructing motherhood and breastfeeding as something natural, free of social conventions and troublesome intrusions like gender equality (Símonardóttir, 2016a). In some cases, this seems to lead to shaming and harassment of mothers who do not comply with the stated norm (Símonardóttir, 2016b). This focus is surprising, and even more so in light of the fact that the government's gender equality plans have included an emphasis on getting fathers more involved during pregnancy. Still it resonates with studies showing a certain disciplining of mothers that do not make full use of their parental leave while the fathers that use more than the paternity leave reserved for them are praised highly by friends and relatives. 
This article will focus on the discrepancy between on the one hand the stated goals of the state of drawing men, particularly fathers, into traditional female dominated areas such as caregiving of infants and young children. On the other hand there is the mothercentred discourse and the workings of a group of experts in one crucial area where fathers have been discursively situated as no more than valuable assistants to the all-important mother-child dyad. We base this article on ongoing research by both authors on the construction of fatherhood and motherhood in a country generally seen as advanced in regard to gender equality. The second author of this article has examined dominant discourses of motherhood and mothering in Iceland and uses interviews with mothers, expectant mothers and midwifes, coupled with a discursive analysis of narratives from mothers who have struggled with breastfeeding. The first author is involved in a longtime project on the creation of masculinities in Iceland, based on qualitative interviews, quantitative surveys, discourse analysis of books and periodicals in the last two centuries, and policy analysis. The article is therefore an attempt at a partial synthesis of our research where the main emphasis is on the last two decades.

\section{The goal of shared parenting in Iceland}

Icelandic politicians have, as their counterparts in the other Nordic countries, for decades subscribed to the idea that state resources could and should be used to promote gender equality and similar possibilities for men and women in all aspects of life. These initiatives have mainly been aimed at improving the status, situations and possibilities of women, thus making their life cycle more like the life cycle of men. The project has generally been successful. The labour market participation of men and women in Iceland is now fairly similar as 85.7 per cent of men and 79.3 per cent of women are active in the labour market. Political representation of women is high, they now occupy 48 per cent of the seats in the Icelandic parliament and the situation is similar in the communes (Statistics Iceland a). The success of the whole project can, for example, be seen in the ranking of Iceland in the Gender Gap list published yearly by the World Economic Forum, where Iceland has topped the list for eight consecutive years (World Economic Forum, 2016). The international press has run headlines about Iceland such as 'The most feminist place in the world' (Johnson, 2011) and The Economist has declared Iceland to be the best place in the world to be a working woman (The Economist, 2016).

This Nordic ideal of gender equality brought with it the vision of shared parenthood, in effect that we should strive for a society characterised by couples where both are active in the labour market and both take care of their children. One of the main steps taken in the Nordic countries in the last decades to change the division of labour within families was to make part of the parental leave non-transferable between parents, in effect reserving a part of it exclusively for fathers (Ellingsæter and Leira, 2006; Duvander and Lammi-Taskula, 2011). The approach has met with a fair amount of success as a great majority of fathers in all the countries use the time allotted to them (Halrynjo and Kitterød, 2016).

Still, the gender difference in the Nordic countries is probably nowhere more pronounced than when it comes to parenthood, because women are always seen as mothers or potential mothers, without regard to their actual status or wishes (Phoenix and Woollett, 1991; Kugelberg, 2006; Perälä-Littunen, 2007). 
Fathering, or the role of the father, has changed very much in Iceland in the last decades as it has in the other Nordic countries and indeed a large part of the Western world. Following the entry of married women, mothers, in the labour market in the sixties and seventies, the (slow) eroding of the provider role of men began, which also meant increased opportunities for them to participate more actively in family life, particularly perhaps to spend more time with their children. The general literature on fatherhood traces different trajectories and differing experiences in changing fatherhood in the Western world (Marsiglio and Pleck, 2005; Oechsle et al., 2012) but, at least in the Nordic countries, it seems that the changes have brought with them increased participation of fathers in child care and a genuine involvement by fathers in the lives of their offspring (Plantin, 2001; Eydal and Rostgaard, 2015). Recent studies have also shown that young Nordic men incorporate the role of the caring father into their ideas about masculinities (Johansson and Klinth, 2008; Jóhannsdóttir and Gíslason, 2017).

\section{Paternal involvement, not shared parenting}

In Iceland, all women attend antenatal clinics throughout their pregnancies, staffed by midwives who provide care before, during, and after the birth. Most births take place at the University Hospital in Iceland and the remainder in smaller maternity units around the country (Directorate of Health, 2017). As in most other Western countries Icelandic fathers began to be present at the birth of their children in the seventies and eighties. This was really the first major area of change from the traditional breadwinner/absent father role of men and in spite of some suspicions in the beginning it soon became obvious that men wanted to participate, wanted to be present at this turning point in their family's life.

Even though this change was in many ways a revolt by women against the medicalisation of the birth process and the powerlessness of the mothers-to-be (Madsen et al., 1999) it also sought strength and justifications in the other social changes that were taking place, not least the increased independence of women following their entry into the labour market. This brought with it the general idea that the roles of men and women were not fixed but could (and should) change, also within the home; in family life.

During the nineties it became increasingly obvious that a focus solely on the situation of women was becoming too narrow to continue the development towards gender equality in Iceland. It was not enough to change the situation of women; something also had to be done in order to broaden the social possibilities of men. This led to a number of initiatives, reports, committees and changes in laws, two of which were most important. The first one, from 1992 was a change in the law on child custody following divorce. The change meant that couples could continue to share custody of their children after divorce. This had a huge impact as the percentage of couples making use of this option rose sharply from 6.2 per cent in 1992 to 89.8 per cent in 2011 (the last year for which figures are available) (Statistics Iceland b). This meant a much closer general relationship between the children and the parent that the child did not live with, most usually the father. The continuation of this change has been that a growing proportion of children of divorced parents now live equally with both their parents (Júlíusdóttir et al., 2016). This also enhanced the idea that fathers were more than just breadwinners. They should be active partners in the lives of their children regardless of their relationship with the mother.

The second important law was passed in the year 2000 when the Icelandic parliament unanimously adopted a new law on parental leave, extending it from six to nine months, 
raising economic compensation from low flat-rate benefit to 80 per cent of salary and dividing the nine months so that three are sharable while each parent has three that are strictly non-transferable (Gíslason, 2007). This had an immediate effect and for most of the years since, around 90 per cent of fathers have made use of their right to parental leave and use on average around 100 days (Arnalds et al., 2013). The stated goals of the law were to ensure that children receive care from both parents and to make it easier for both men and women to combine family life and participation in the labour market (Act on maternity and paternity leave, 2014). Studies have shown the change to have had a positive impact on the participation of fathers in care-giving both during and after parental leave, (Gíslason, 2007, 2008; Arnardóttir, 2008; Arnalds et al., 2013) and the relationship between fathers and their children (Arnarsson and Gunnpórsdóttir, 2016).

All-in-all the state has taken serious steps to increase the possibilities of active fatherhood and on the whole the steps have been successful. Many more fathers are now active caretakers than ever before in Iceland's history. These steps have been taken under the explicit banner of promoting a dual earner - dual carer family life. The success so far strongly suggests that this resonates well with general views. However, there are other players and other discourses present and not all promoting active fatherhood.

Studies and statistics have shown that in spite of the emphasis on gender equality in Iceland, parenthood, particularly regarding caring for infants, tends to be traditionally gendered within families. To begin with, mothers use on average the three sharable months of parental leave (Arnalds et al., 2013). There seems to be a tendency that those mothers who do not use all of their available months are stigmatised (Gíslason, 2005), something that has also been observed in qualitative studies in the other Nordic countries (Olsen, 2000; Lammi-Taskula, 2007). Mothers, to a much higher degree than fathers, reduce their participation in the labour market to bridge the gap from parental leave to day-care (Jónsdóttir, 2007; Ingólfsdóttir and Gíslason, 2016). When parents describe their use of parental leave and the decisions made on how to divide it and how to bridge the care gap, it is obvious that the wishes of mothers are the deciding factor (Gíslason, 2005; Farstad, 2014; Ingólfsdóttir and Gíslason, 2016). Finally, even though opinion polls show a massive support for the Icelandic law on parental leave (Eydal and Gíslason, 2016), when parents were asked in a survey in 2007 how they would like to see the ideal parental leave, they advocated a much longer leave for mothers than for fathers (Jónsdóttir, 2007).

So it seems that despite policy measures aimed at increasing gender equality and shared parenting; parental practice and the ideology surrounding the care of infants is somewhat out of step with that. The reason might be a strong discourse portraying the mother as the 'self-evident' parent during the first months after birth while it seems to be more of a question if fathers are indeed up to the role of an active, caring parent.

\section{Making men into fathers}

According to the law on gender equality from 1985 each new government is required to present to the Icelandic parliament a four year plan on what it intends to do to increase gender equality. Usually this has been broken down to what each ministry intends to do within its jurisdiction. After the four years a report on implementations is to be submitted to the parliament and debated there. The plan presented in 1997 by the Icelandic government was the first one to mention prenatal information for fathers as one of the objectives of the Ministry of Health. The wording was careful: 
Steps will be taken to initiate education for prospective fathers as part of the programme offered to prospective parents. Also an effort will be made to ensure that those working in the health care system are aware of the importance of fathers being active participants during pregnancy, birth and in taking care of their children (bingsályktun, 1997: art. 6.5).

When the implementation report was presented it emerged that nothing had been done. Similar mentioning of prenatal courses for fathers was in the plan for 2004-2008, and when the implementation report was presented the initiative seemed to have been very successful:

Father's education has been a part of antenatal courses at the Centre for Maternity Care for many years. When the maternity care provisions were re-organized in 2006 the father's education was also re-organized. Since fall 2007 all prospective fathers have been offered father's education and, in addition, their fathers, prospective grandfathers, are also welcome together with their sons. The course is held once a month, discussing the role of the father, the family and the care of infants. This is only for men. In the beginning very few came but after a while participation started to increase... This has gained a good reputation and satisfaction is general (Skýrsla félags- og tryggingarmálaráðherra, 2009: 95).

Despite the good intentions these initiatives proved relatively short-lived even though a qualitative study among Icelandic prospective fathers seems to indicate a need for antenatal courses to involve men more and focus on social and economic issues as well as the role of the fathers during pregnancy and birth (Gottfredsdóttir, 2005). The initiatives were for the most part driven by dedicated midwifes and when they left or retired, or funding was cut, the continuation proved to be difficult. When one of the authors enquired in January 2017 at the Centre for Maternity Care about the practice today it emerged that there is no longer any education for prospective fathers within the health care system. When asked why this had been abandoned the reply was that there had been cuts in funding and since almost all fathers made use of their right to parental leave it was thought unnecessary to encourage their participation.

A similar discrepancy between the ideal of gender equality and parenthood has been observed by one of the authors in an unpublished study of books and pamphlets published in Iceland between 1846 and 2010 that focused on instructing (potential) parents on pregnancy and birth, and how best to care for their new-born babies and raise them in the first years. Three periods can be detected. Up to the sixties the father is almost completely absent in this literature and when mentioned it is mainly as a breadwinner. Between the sixties and the turn of the century the existence and presence of fathers is more and more acknowledged, but mainly as the mothers' slightly clumsy and unsure helper. Beginning in the nineties we both get an increase in focus on fathers and their independent participation in child care and also books either written by fathers on their experience or books solely addressing fathers.

However, although no parental book would be published today that solely referred to the mother, the tendency to equate motherhood and parenthood is obvious in the latest books. For example a book published in 2010 called Foreldrahandbókin [The Parents' Handbook] (Sigurðardóttir, 2010) starts out by addressing both parents and dutifully includes the father here and there. There is even a chapter called 'Becoming a father', but symptomatically, no chapter on becoming a mother since the whole book (unintentionally) promotes the idea that the mother is the main parent and often the text 
glides effortlessly between 'mother' and 'parent'. This can also be seen in other aspects of the book. Besides the author, twenty-six individuals write short pieces in the book relating their experience or expertise, five of them are men. Spread through the book are short quotations from parents, 488 all-in-all. Eighteen or 3.7 per cent are from fathers. So even though the stated objective is to write a book for both parents, the reality of parenthood as in fact meaning motherhood is evident.

\section{Mothering: through bonding and breastfeeding}

Sharon Hays's (1996) analysis of the ideology of intensive mothering was an important addition to the literature on parenting and, especially, motherhood, and has relevance to current discourses on motherhood in Iceland. As parenting has become an increasingly important part of adult identity in Western countries, successful child-rearing has become defined as a practice which is 'child-centred', whereby the mother is expected to immerse herself in child-rearing and take full responsibility for her child's development, while relying on expert guidance and science to show her how (Lee et al., 2014). Many scholars have picked up on Hay's concept of intensive mothering to describe the contemporary parenting experience in Western countries (Freely, 2000; Elvin-Nowak and Thomsson, 2001; Hochschild, 2002; Douglas and Michaels, 2004; Maher and Saugeres, 2007; Faircloth, 2013; Wolf, 2013; Lee et al., 2014), recognising the paradox that this intensive, expert-led type of mothering coincides with women's increased participation in the labour force (Hays, 1996; Kanieski, 2010).

A study on attachment theory discourse present in educational materials for Icelandic parents has shown that these materials incorporate classic ideas about the primacy of the mother and the intensification of motherhood where little effort has been made to incorporate fathers into the discourse or to include them as meaningful agents when it comes to attachment and bonding or to promote a culture of shared parenthood (Símonardóttir, 2016a). Although most of the educational materials simply address mothers directly, some effort has been made to introduce a more inclusive, gender neutral language of 'care-givers' or 'parents' but more often than not the language reverts back into 'mother' language. Fathers are not expected to fully inhabit the role of care-giver in the same way mothers are; and their bodies, thoughts and actions are not scrutinised or pathologised to the same degree (Símonardóttir, 2016a).

The focus on exclusive breastfeeding in Iceland is also an important factor when it comes to parenting ideals and the lived experiences of parenting. The prevalence of breastfeeding is traditionally very high in the Scandinavian countries where we have witnessed an upward trend towards higher breastfeeding rates and duration (Thome et al., 2006). Almost all Icelandic mothers initiate breastfeeding (Directorate of Health, 2012) and both policy and practice are in line with the World Health Organization recommendations. A recent study on the experiences of Icelandic mothers who had struggled with breastfeeding or been unable to breastfeed reveals how closely linked their self-identity as mothers is with being able to breastfeed and how they often have to account for their infant feeding practices to friends, family and even strangers. Mothers who are unable to breastfeed often feel that their mothering capabilities and devotion to their child are being ranked and compared, especially by other mothers who judge them both consciously and unconsciously. Breastfeeding in an Icelandic context represents a 
strong moral and social norm and is not presented as a decision, rather as an obligation and a duty that all women should take on (Símonardóttir, 2016b).

This substantial focus on exclusive breastfeeding and the prevalence of attachment theory discourses and an overall adherence to the ideology of intensive mothering indicate that there are competing discourses at play. Powerful biomedical discourses proclaim that motherhood should be regarded as natural and outside social formations and feminist or other gender equalitarian discourses have been unsuccessful in addressing and providing parents with counter discourses that challenge the highly gendered elements of this discourse and its link to idealised versions of motherhood.

There is agreement within the health service that it is important that fathers are active and participate during pregnancy, birth and in the care-taking of the infant, but still fatherhood is not seen as something that can be on a par with motherhood. Similarly gender equality is regarded as important but is also seen as a social reality that has little to do with the sanctity of motherhood and the essential bond between mother and the child. Consequently gender equality is constructed as something in the outside world, bracketed as unimportant during the unfolding of pregnancy, birth, breastfeeding and bonding.

\section{Discussion}

In the last few decades Icelandic politicians and activists have increasingly focused on the situation and role of fathers in an effort to increase gender equality as women's responsibilities for housework and child care has been shown to be detrimental to their possibilities in the labour market and one of the major reasons for the persistent gender pay gap. Changes in laws in the area have proven successful and in many areas the positive aspects of this change have been documented. At the same time there seems to be an ongoing discourse that glorifies and promotes motherhood over fatherhood or shared parenting, especially during the early months and years of the baby's life. This can be seen in a number of areas but perhaps the most important one is the maternity care services where the emphasis on the participation of fathers that was promoted by the gender equality plans of different governments has disappeared but the essentialist discourses on the sanctity of motherhood and mother-child bonding have prevailed.

What has in effect been taking place is that the maternity care services have been moving towards an essentialist view of motherhood and breastfeeding while (perhaps unconsciously) excluding fathers from the process. This may partly reflect a general atmosphere among Icelanders, namely that motherhood and breastfeeding are seen as natural and almost holy while the inclusion of fathers may be good, but not really necessary, especially during the first months after birth. This bracketing of gender equality when motherhood is discussed has also been noted in some of the other Nordic countries. Elvin-Nowak and Thomsson (2001) have shown that Swedish mothers 'must construct their motherhood within the context of a gender-equality discourse, but in an everyday reality that is not gender equal' (Elvin-Nowak and Thomsson, 2001: 410) and this, we would argue, holds true for Icelandic mothers as well. As discourses on equality and shared parenting have gained momentum in Iceland it seems even clearer than before that early motherhood is excluded from this narrative. Early motherhood is simply constructed as a time for mothering outside of parenting, where different rules and standards apply.

What this tells us is that despite a strong emphasis on gender equality by politicians and the social partners and a general support for the equal rights and possibilities of 
men and women, it is still the case that women are regarded as the primary, self-evident parent and this is not viewed as a social construct but as a natural phenomenon, fully in accordance with what women want, need and desire since nature has endowed them with the capacity to give birth. Still, this focus on mothers is mainly confined to a particular period, namely the months following birth and the period when the mother is breastfeeding. No political party has suggested that Iceland should abandon the non-transferable fathers' months, and social support, as measured by opinion polls, has grown (Eydal and Gíslason, 2016). Nevertheless the ideology of intensive mothering has been gaining support and is, at least partially, advocated by some maternity care service providers and has become more pronounced in the general discourse on parenting in recent years.

The Nordic countries are routinely held up as the exemplary model in terms of policy making when it comes to equality measures and structural factors that promote equality in the workplace and in the home. This narrative of 'the equal Nordic countries' can disguise other aspects of the parenting culture and the distribution of care-work that do perhaps not fit as well in to that particular narrative. Faircloth (2013) has noted how intensive motherhood has been imported from the US and UK to other cultural settings where its interpretation and representation can be very different. In France, as Badinter (2012) and Faircloth (2013) have shown, where there is rich feminist history and a historic recognition of women's identities beyond motherhood, intensive mothering is seen as a threat to the feminist cause and to women's liberty. Therefore, we believe that it would be particularly important to see an increase in research on parenting in the Nordic countries that would examine the coexistence of shared parenting and intensive mothering narratives and critically engage with the pull towards intensive mothering within the context of Nordic feminism.

\section{References}

Act on Maternity/Paternity and Parental Leave no. 95/2000 (2014) http://www.althingi.is/ lagas/nuna/2000095.html [accessed 24.09.2014] [accessed 24.11.2016].

Arnalds, Á. A., Eydal, G. B. and Gíslason, I. V. (2013) 'Equal rights to paid parental leave and caring fathers - the case of Iceland', Stjórnmál og stjórnsýsla 9, 2, 323-44.

Arnardóttir, A. A. (2008) 'Fæðingarorlof frá sjónarhóli feðra og mæðra' [Parental leave from the standpoint of fathers and mothers], in G. P. Jóhannesson and H. Björnsdóttir (eds.), Rannsóknir í félagsvísindum IX [Social science studies IX], Reykjavík: Félagsvísindastofnun Háskóla Íslands, 139-50.

Arnarsson, Á. and Gunnoórsdóttir, H. (2016) 'Íslenskir feður - bestir í heimi?' [Icelandic fathers - best in the world?], in H. Ólafsdóttir and T. M. Hejstra (eds.), pjóðarspegillinn 2016, http://hdl.handle.net/1946/26371 [accessed 26.01.2017].

Badinter, E. (2012) The Conflict: How Modern Motherhood Undermines the Status of Women, (A. Hunter, Trans. [Le conflict: La femme et la mére]), Toronto: Harper Collins Publishers Canada (Original work published 2010).

Directorate of Health (2012) Brjóstagjöf og næring [Breast feeding and nutrition], http://www.landlaeknir.is/ servlet/file/store93/item16573/brjostagjof_og_naering_2004-2008_juni.2012.pdf [accessed 26.01.2017].

Directorate of Health (2017) Fæðingaskrá [Birth registration], http://www.landlaeknir.is/tolfraediogrannsoknir/tolfraedi/faedingar/ [accessed 26.01.2017].

Douglas, S. and Michaels, M. (2004) The Mommy Myth: The Idealization of Motherhood and How It Has Undermined Women, New York: Simon and Schuster. 
Duvander, A.-Z. and Lammi-Taskula, J. (2011) 'Parental leave', in I. V. Gíslason and G. B. Eydal (eds.), Parental Leave, Childcare and Gender Equality in the Nordic Countries, Tema Nord 2011:562, Copenhagen: Nordic Council of Ministers, 29-82.

Ellingsæter, A. L. and Leira, A. (eds.) (2006) Politicising Parenthood in Scandinavia: Gender Relations in Welfare States, Bristol: Policy Press.

Elvin-Nowak, Y. and Thomsson, H. (2001) 'Motherhood as idea and practice: a discursive understanding of employed mothers in Sweden', Gender and Society, 15, 3, 407-28.

Eydal, G. B. and Gíslason, I. V. (2016) 'Caring fathers and parental leave in prosperous times and times of crisis: the case of Iceland', in G. B. Eydal and T. Rostegaard (eds.), Fatherhood in the Nordic Welfare States, Bristol: Polity Press.

Eydal, G. B. and Rostgaard, T. (eds.) (2015) Fatherhood in the Nordic welfare States: Comparing Care Policies and Practice, Bristol: Policy Press.

Faircloth, C. (2013) Militant Lactivism? Attachment Parenting and Intensive Motherhood in the UK and France, New York: Berghahn Books.

Farstad, G. R. (2014) 'Difference and equality: Icelandic parents' division of parental leave within the context of a childcare gap', Community, Work and Family, 18, 351-67.

Freely, M. (2000) The Parent Trap: Children, Families and the New Morality, London, England: Virago Press Ltd.

Gíslason, I. V. (2005) 'Feður sem taka lengra fæðingarorlof' [Fathers who take longer parental leave], in Ú. Hauksson (ed.), Rannsóknir í félagsvísindum VI [Social research VI], Reykjavík: Félagsvísindastofnun Háskóla Íslands.

Gíslason, I. V. (2007) Parental Leave in Iceland. Bringing the Fathers in, Akureyri: Centre for Gender Equality.

Gíslason, I. V. (2008) 'You are regarded as weird if you don't use the paternity leave', in G. B. Eydal and I. V. Gíslason (eds.), Equal Rights to Earn and Care - Parental Leave in Iceland, Reykjavík: Félagsvísindastofnun Háskóla Íslands, 87-109.

Gottfredsdóttir, H. (2005) 'Prospective first-time fathers and their views on fatherhood in the context of the new policy on parental leave in Iceland', Birth Issues, 14, 4, 128-34.

Halrynjo, S. and Kitterød, R. H. (2016) Fedrekvoten - norm for fedres permisjonsbruk i Norge og Norden. En litteraturstudie [The fathers' quota - Norm for fathers' leave use in Norway and the Nordic countries. A literature review], Oslo: Institutt for samfunnsforskning, Rapport 2016:06.

Hays, S. (1996) The Cultural Contradictions of Motherhood, New Haven and London: Yale University Press.

Hochschild, A. (2002) The Second Shift: Working Families and the Revolution at Home, New York, NY: Penguin Books.

Ingólfsdóttir, E. S. and Gíslason, I. V. (2016) 'Gendered solutions to the care gap issue in Iceland', NORA - Nordic Journal of Feminist and Gender, 24, 4, 220-33, DOI: 10.1080/08038740.2016.1241826.

Johansson, T. and Klinth, R. (2008) 'Caring fathers. The ideology of gender equality and masculine positions', Men and masculinities 11, 1, 42-62.

Johnson, J. E. (2011) 'The most feminist place in the world', The Nation, http://www.thenation.com/ article/158279/most-feminist-place-world\# [accessed 19.09.2014].

Jóhannsdóttir, Á. and Gíslason, I. V. (2017) 'Young Icelandic men's perception of masculinities', The Journal of Men's Studies, http://journals.sagepub.com/doi/full/10.1177/1060826517711161.

Jónsdóttir, B. (2007) Upplifun foreldra á fæðingarorlofi [The experience of parents on parental leave] (Unpublished MA thesis), Departments of Business and Economics, University of Iceland.

Júlíusdóttir, S., Sigurðardóttir, S. and Pálsdóttir, D. (2016) 'Raddir skilnaðarbarna: Um jafna búsetu hjá foreldrum eftir skilnað' [The voices of children of divorced parents: On the equal living with parents after divorce], Tímarit um uppeldi og menntun, Icelandic Journal of Education, 25, 1, 323.

Kanieski, M. A. (2010) 'Securing attachment: the shifting medicalisation of attachment and attachment disorders', Health, Risk and Society, 12, 4, 335-44. 
Kugelberg, C. (2006) 'Constructing the deviant other: mothering and fathering at the workplace', Gender, Work and Organization, 13, 152-73.

Lammi-Taskula, J. (2007) Parental Leave for Fathers? Gendered Conceptions and Practices in Families with Young Children in Finland, Vaajakoski: Stakes.

Lee, E., Bristow, J., Faircloth, C. and Macvarish, J. (2014) Parenting Culture Studies, London: Palgrave Macmillan.

Madsen, S. A., Munck, H. and Tolstrup, M. (1999) Fædre og fødsler [Fathers and Delivery], Copenhagen: Frydenlund Grafisk.

Maher, J. and Saugeres, L. (2007) 'To be or not to be a mother? Women negotiating cultural representations of mothering', Journal of Sociology, 43, 1, 5-21.

Marsiglio, W. and Pleck, J. H. (2005) 'Fatherhood and masculinities', in M. S. Kimmel, J. Hearn and R. W. Connell (eds.), Handbook of Studies on Men and Masculinities, Thousand Oaks, London, New Delhi: Sage, 249-69.

Oechsle, M., Müller, U. and Hess, S. (eds.) (2012) Fatherhood in Late Modernity, Opladen: Verlag Barbara Budrich.

Olsen, B. M. (2000) Nye fædre på orlov. En analyse af de kønsmæssige aspekter ved forældreorlovsordninger [New fathers on leave: analysing the gendered aspects of systems of parental leave], Copenhagen: Köbenhavns Universitet.

Perälä-Littunen, S. (2007) 'Gender equality or primacy of the mother? Ambivalent description of good parents', Journal of Marriage and Family, 69, 341-51.

Phoenix, A. and Woollett, A. (1991) 'Motherhood: social construction, politics and psychology', in A. Phoenix, A. Woollett, and E. Lloyd (eds.), Motherhood: Meanings, Practices and Ideologies, London: Sage, 13-27.

Plantin, L. (2001) Mäns föräldraskap. Om mäns upplevelser och erfarenheter av faderskapet [Men's parenting. On men's perceptions and experiences of fatherhood], Göteborg: Göteborgs Universitet.

Sigurðardóttir, P. (2010) Foreldrahandbókin [The Parents' Handbook], Reykjavík: Salka.

Símonardóttir, S. (2016a) 'Constructing the attached mother in the 'world's most feminist country', Women's Studies International Forum, 56 (May), 103-12, doi:10.1016/j.wsif.2016.02.015.

Símonardóttir, S. (2016b) 'Getting the green light: experiences of Icelandic mothers struggling with breastfeeding, Sociological Research Online, 21, 4, 1.

Skýrsla félags- og tryggingarmálaráðherramálaráðherra (2009) 'Skýrsla félags- og tryggingarmálaráðherramálaráðherra um stöðu og próun jafnréttismála' [Report by the minister for social- and social policy issues on the situation and development of gender equality], http://jafnretti.is/D10/_FILES/Jafnrth2009_net.pdf [accessed 23.03.2017].

Statistics Iceland a, https://hagstofa.is/talnaefni/samfelag/felagsmal/konur-og-karlar/ [accessed 23.03.2017].

Statistics Iceland b, https://hagstofa.is/talnaefni/ibuar/fjolskyldan/skilnadir/ [accessed 29.11.2017].

The Economist (2016) 'The best - and worst - places to be a working woman', http://www.economist.com/ blogs/graphicdetail/2016/03/daily-chart-0 [accessed 26.01.2017].

Thome, M., Alder, E. M. and Ramel, A. (2006) 'A population-based study of exclusive breastfeeding in Icelandic women: is there a relationship with depressive symptoms and parenting stress?', International Journal of Nursing Studies, 43, 1, 11-20.

Wolf, J. B. (2013) Is Breast Best: Taking on the Breastfeeding Experts and the New High Stakes of Motherhood, New York: NYU Press.

World Economic Forum (2016) The Global Gender Gap Report 2016, http://www3.weforum.org/ docs/GGGR16/WEF_Global_Gender_Gap_Report_2016.pdf [accessed 26.01.2017].

pingsályktun (1997) http://www.althingi.is/altext/122/s/1452.html [accessed 23.03.2017]. 